this was recently undertaken by the sociologist Maurice Roche in his Phenomenology, Language and the Social Sciences. Such a book would have been welcome especially if written by someone with direct experience of psychoanalytic work. But the title is misleading: the book is a dictionary, and sets out to elucidate, in detail, the accepted meanings of the many concepts used in psychoanalysis, including an account of their evolution.

In a short introduction Daniel Lagache justifies psychoanalytical terminology, maintaining that "ordinary language has no words to evoke mental structures and tendencies that do not exist for common sense." But do mental structures of the kind proposed by Freud exist? Is there really an id? Surely it is the naive acceptance of such an idea that has led Freudian theory into much disrepute? The question as to how to describe "tendencies that do not exist for common sense" is more debatable. Freudian theory seems to have gone astray here too-but it is not alone in so doing, being in the company of traditional psychiatry and psychology and most if not all disciplines which have attempted a "scientific" account of human meaning and behaviour. The more the language departs from that of ordinary common sense the greater it removes itself from psychological reality and in the end we are lost in a mass of jargon and a complexity of tautologies.

Because the authors do not question Freud's basic intellectual stance the book is vulnerable to criticisms of this kind. It lacks the objectivity of Charles Rycroft's delightful but all too short Critical Dictionary of Psychoanalysis. But having expressed my dissatisfactions with the book I must confess to an admiration for it. It is clear and scholarly, avoids tautology as far as can be done in the context of the task and gives a tight discussion not only of the usage of terms but some of the relevant problems of psychoanalysis to which they refer.

Peter Lomas

\section{Cell membrane systems}

Comparative Organellography of the Cytoplasm. By A. Frey-Wyssling. (Protoplasmatologia, Vol. III/G.) Pp. vii +106. (Springer-Verlag: Vicnna and New York, 1973.) 296 schillings; 42.40 DM; $\$ 23.90$.

TiIs is a shori, account of the present state of knowledge about the membrane systems, microtubules and microfilaments of plant and animal cells. It is very condensed but because the subject matter is presented from such a definite viewpoint, the ideas and theories are very stimulating. The generalisations do, however, in most cases need more reservations and qualifications than they are given. In this connection it is a pity that in such a short book space is given up to discussions of the Greek origins and other aspects of nomenclature rather than an amplification of conclusions.

Because of its condensed form and the bias that is given to the subject matter the book is rather unsuitable as background reading for elementary students. Most workers in the field will, however, find it very interesting, and although they may not agree with all the ideas the account does give an overall perspective that may well be lost by concentration on one particular aspect of this very important and exciting field of biology.

\section{H. Northcore}

\section{Cinderella controllers}

Control and Urban Planning. By J. Brian McLoughlin. Pp. 287. (Faber: London, October 1973.) 33.95 .

Brian McLoughis draws together two threads in his latest book: his long standing interest in the theory of control, and the results of a research project on development control in planning. IIe discovered that the development controllers, planning's caseworkers, feel themselves to be the Cinderellas of planning: the whizz kids go into 'strategy' or 'research'. And yet it can be argued, as it is here, that the esscnce of planning is control, that its main instrument is development control, and so the latter must be connected to the latest research in the field of the former.

The argument is set out at follows. An historical account of the nature and instruments of control in planning. including an effective review of official reports and government publications, is given in chapters $1-5$. The implications of the 1968 Act, and structure planning, are taken up in chapter 6 . The need for a more explicit treatment of policy making is identified and this is pursued in chapter 7. The theory of control and its application in urban planning, largely from the viewpoint of cybernetics (Ashby, Klir, Valach, and Beer loom large) is presented in chapters 8 and 9 , and is connected to the issues for urban planning identified in earlier chapters. Some recommendations are prosented in chapter 10.

What emerges from the argument? The early emphasis on development control leads to an exceptionally well balanced approach overall, as this aspect is usually neglected. It also brings to the fore the need for a more explicit treatment of policy. General strategic statements are insufficient for the needs of the development controller. Considerable illumination is cast using the theory of control. Three examples will suffice. First, Beer's concepts of hierarchies in control systems, and associated differences in language between levels, show that there is an as yet unbridged gap between strategy and micro decision levels. Second, Ashby's law of requisite variety helps to determine necessary characteristics of the control system. Third, several levels of resolution are needed, and the two problems cited above will look different at different levels.

All of this will stimulate future research. One of the main roles of the book, however, will be to connect planners who have had a traditional educalion to these newer ideas, and such. exposition has always been McLoughlin's forte. It is a happy accident that the argument is rooted in development control and the iseues raised by the demands of structure planning, as the reader is immersed in this before being led gently into control theory. The myth that control theory leads to government by computer is laid bare. The traditional planner will almost be forced to recognisc that the new insights will help, and indeed are necessary, for any underpinning value system. The 'new planning' is clearly scen as an aid to the political process and not a substitute for it.

It is possible that a few people will be put off by cybernetic jargon, and it remains an interesting speculation that although this presentation is sufficient, it may not be necessary! There may be other perspectives from which some of the new idcas can be explained to a wider public. It is also possible that the cybernetic vicwpoint sometimes forces a view of urban systems as such (as distinct from associated planning processes) which overemphasises, say, homeostatic adjustment, relative to other systems analytical approaches-such as statistical averaging or accounting procedures. But in relation to the main purposes of the book these criticisms are minor. Its arrival is most timely. Urban planners are attempting to be more scientific. The traditional concerns of physical planning are having to be integrated with many other ficlds of urban government into systems of government. New local authorities take over from the old in April 1974. The author provides an excellent agenda of the issues facing them and many insights towards solutions to problems. The book is well written, easy to read and descrves a wide audience.

A. G. WILsON 